\title{
How do student teachers learn professional digital competence?
}

\author{
Louise Starkey \\ School of Education \\ Victoria University of Wellington, New Zealand \\ Louise.Starkey@vuw.ac.nz \\ Anne Yates \\ School of Education \\ Victoria University of Wellington, New Zealand \\ Anne.Yates@vuw.ac.nz
}

\begin{abstract}
Students entering the teaching profession need to develop professional digital competencies to teach in a digitally infused education system. This paper explores what student teachers self-learn and what needs to be taught in initial teacher education programmes in course work or on school placement. A mixed method approach was implemented with data gathered through focus group interviews and surveys of elementary and high school student teachers and their teacher educators. The results indicate three sites of learning with regards the use of digital technologies: student teachers are predominantly self-taught; their teacher education courses introduce them to technologies and they learn how to use educational technologies when on school placements. The implications are that student teachers do not need to be taught how to use most technologies, they do however, need to learn what educational technologies to use and how to make decisions about technology use in their initial teacher education programmes.
\end{abstract}

\section{Introduction}

Digital tools including the Internet, computational devices, applications and websites have been introduced into education systems over the past 30 years. They are becoming infused across teaching and learning processes as student records, communication, learning activities and teacher planning become digitised (Selwyn, Nemorin, Bulfin, \& Johnson, 2018). In a digitally infused education system digital technologies and applications will influence the broad work of being a teacher. For example, music teachers may need to realign their knowledge of contemporary practices to develop digital musicians, voice activated artificial intelligence may become a virtual assistant for teachers of young children providing rich data of interactions and learning progressions, and the availability of data about each student's history of learning and experiences may reframe curriculum, pedagogy and the work of a teacher. When a student graduates from an initial teacher education (ITE) programme they should be confident in their ability to be a beginning teacher within the current and future context of schooling (Zeichner, 2012). As schools become digitally infused the job of the teacher evolves and teachers entering the profession need to be prepared to enter this type of education system.

\section{Literature review}

Student teachers' learning experiences through coursework, school placement and informal learning have been explored in the literature (Tang, Wong, Li, \& Cheng, 2019). Learning during school placement includes three components; learning how to teach, manage the learning environment and how to be a teacher (Starkey, 2020). Learning in coursework, usually includes subject-matter studies, foundation of education studies, and methods studies (Darling-Hammond, 2007). The research exploring the relationship between the aspects has identified that student teachers in the past prioritized practice over coursework (Hobson et al., 2008; Tang, Wong, \& Cheng, 2012). However, each aspect of a programme of learning to teach contributes to the process of learning to teach when there is a non-hierarchical interplay between academic, practitioner, and school based-expertise (Zeichner, 2010). Studies examining how student teachers learn should consider each of these three components.

Research exploring the preparation of teachers for the digital age has potential to inform future programmes and practices. A systematic review of literature identified what had been studied regarding the preparation of teachers for digital contexts (Starkey, 2020). Research has examined how confident student teachers are to integrate particular technologies into their practice (Kabakci Yurdakul \& Çoklar, 2014), personal characteristics or dispositions of student teachers (for example, Tondeur, Scherer, Siddiq, \& Baran, 2017), pedagogical 
approaches within ITE (Røkenes \& Krumsvik, 2014), and the design of programmes (Shanti Divaharan, WeiYing Lim, \& Seng-Chee Tan, 2011). How students learn professional digital competence is an emerging area in the literature.

The notion of teacher professional digital competence (Gudmundsdottir \& Hatlevik, 2017; Instefjord \& Munthe, 2017) provides a conceptual basis for considering how we prepare student teachers to be teachers in a digitally infused schooling system. Teacher professional digital competence includes three aspects; teaching, managing the digital learning environment and the professional work of being a teacher (Starkey, 2020). Within this, a professionally digital competent teacher not only uses technology in their teaching, they also organise and manage the digital learning environment; they use technology in the physical environment and they develop the online learning environment for their students. The professional work of a teacher includes using student management systems to record and access information to inform practice and using communication tools to participate in professional learning networks and to communicate within the school community. Ideally, teachers will be professionally digitally competent when they begin teaching.

The digital age provides the opportunity for adult learners to have a range of access to knowledge and expertise from which they can learn informally (Blaschke \& Hase, 2016). Student teachers are agentic in their learning (Toom, Pyhältö, \& Rust, 2015) and enter the profession with varying degrees of knowledge of how to use technology and experiences as learners. As adult learners they experience both andragogy (Merriam, Caffarella, \& Baumgartner, 2006) within the formal learning and curriculum within their teacher education programme, and as autonomous learners they apply the principles of heutagogy (Hase \& Kenyon, 2000) to self-identify and access knowledge or skills as needed. The notion of heutagogy (self-determined learning) provides a theoretical basis for recognising that learning does not only occur through the taught curriculum.

The aim of this study is to identify where or how student teachers learn professional digital competence. This knowledge can inform where professional digital competence should be embedded across the different aspects of ITE programmes.

\section{Methods}

This mixed method case study was carried out with initial teacher education students and teacher educators in one higher education institution in New Zealand. Case study design enables the exploration of a specific bounded system (Stake, 2006) which, in this study, focused on how and where student teachers learn to use digital technologies for their teaching practice. Both quantitative and qualitative data were collected to more thoroughly answer the research questions (Creswell \& Plano Clark, 2011). Data sources included an initial pilot of two focus group interviews of students at the end of 2017; this informed the parameters for the surveys such as the types of digital tools to include. Two surveys were developed and applied at the end of 2018, one for the 2018 cohort of student teachers and the other with teacher educators. Two further focus group interviews were undertaken with student teachers to further understand findings from the survey. After initial analysis of the data, a workshop was convened for teacher educators to discuss the results. This discussion was recorded to provide data for the research and context to the results.

The student teacher participants were near the end of a one-year graduate programme preparing them to teach in either elementary or high schools in New Zealand. The programme includes structured learning within course work and school placements but no specific course on teaching with digital technologies. The initial teacher educators taught courses within the elementary and high school programmes. The survey was completed by 68 student teachers, of which 29 were studying to be high school teachers and 49 studying to be elementary teachers and 11 volunteered to take part in the focus groups. Twelve teacher educators completed the survey and nine attended the workshop.

Descriptive statistics were used to analyse the quantitative data. The qualitative data were analysed using abductive reasoning drawing themes from the data and the research literature. Abduction is an interpretivist approach and tries to report how individuals understand reality (Scott \& Morrison, 2006). The abductive process involves exploratory study which creates a guide or theoretical framework for the study. In this case the authors carried out a qualitative pilot study as well as a literature review to frame the subsequent study.

\section{Findings}


The student teachers were asked in the survey where or how they learnt to use a range of digital tools which can be used within the broad context of teacher practices. At the end of the programme all the students knew how to use generic tools such as website searches, multimedia resources and presentation software. For example, generic presentation tools are used in teaching, by the teacher or their students:

I regularly use Youtube for clips and things that are relevant to whatever the lesson might be and that goes across all subject areas as well. (High school student teacher).

The student teachers learnt to use educational technologies with the children they taught during school placements such as dictation software for a first draft of essays, coding software like scratch and writing development tools. One student teacher outlined a range of technologies she had learnt to use in her teaching practice including a digital portfolio tool (Seesaw) that was shared with parents:

We'd post their general work on Seesaw. They might take a picture of the writing that they've done and post on Seesaw or they might just type straight into Seesaw. Some kids using voice typing and these kids with dyslexia and other things that make writing tricky for them. (Elementary school teacher)

Not all had learnt how to use education specific technologies such as student management systems and digital portfolios. Few were familiar with emerging tools such as virtual reality (Figure 1).

Figure 1. Where student teachers reported learning how to use digital technologies.

The results show a pattern across the three aspects of professional digital competence and whether students were learning independently, through courses at the University or through school placement.

\section{Learning independently}

The students predominantly taught themselves to use generic presentation tools themselves. In the focus group interviews students explained how once they were introduced to something they would learn how to use it themselves:

Self taught, grown up with it. ... basic skills of Microsoft Office which learnt at school and then I've built on them myself I guess. (High school student teacher).

However, not all student teachers considered themselves experts when they began teacher education programme:

I didn't know how to use powerpoint, had to relearn for this course. I didn't realise how crap at technology I was. I am a millennial I grew up with it, I should know it. But I am really terrible at it. (High school student teacher).

The students were also asked about newer technologies such as artificial intelligence (such as Siri or Alexa) and virtual reality. While fewer of them were familiar with how to use these, those that did were mainly self-taught or, in the case of virtual reality, $14 \%$ learnt how to use this in their undergraduate degree course and $36 \%$ learnt with friends and family. The student teachers had not yet experienced these emerging technologies in the schooling context and were a low priority to learn with regards to their teaching practice.

The student teachers were self-learning about how to teach using digital technologies, they were also learning a second professional digital competence, how to manage the online learning environment of their students. In the survey the student teachers were asked where they learnt to create multimedia resources. Those who knew how to do this reported that they were self-taught (63\%), although $14 \%$ of the respondents stated that they learnt this at school.

\section{Learning in schools}

Student teachers learnt about the use of technologies within their school placements. Respondents appeared to confound school placements and learning in the workplace when attributing where some learning took place. Educational rather than generic technologies were learnt within the schooling or workplace contexts. These are 
the technologies that would more commonly be seen in an educational context than in a social or work context such as: online quizzes, digital portfolios, Interactive whiteboards, digital games for learning, subject specific applications and student management systems.

The learning in school placement was from mentor teachers, students, and through their own practice.

... the kids were actually showing me that that's what they were doing so they were teaching me. The kids also taught me how to code Bob the Dash robot. (Elementary student teacher)

Some learning took place through organised professional development while on school placement, for example:

We have a fortnightly morning tech session and it's usually where someone has found a new tool and they are showing the rest of the staff how to use it, but sometimes it's more focussed on [the student management system], so teachers are reminded 'this is how you send out a mass email, and this is how you create a group and this is how you do $\mathrm{x}, \mathrm{y}$ and $\mathrm{z}$ '. (High school student teacher).

While some student teachers identified the educational technology they had learnt while on school placement, especially how to use digital portfolios, subject specific technologies and student management systems, others were self-taught.

\section{Learning through teacher education courses}

The university-based teacher educators reported that they are introducing student teachers to digital technology within their course work and believed they taught student teachers about the use of technologies. They said that they were integrating online quizzes, showing students subject specific technologies, and including assignments where students use data from student management systems and leading discussions about how tools are used to manage the learning environment. They also recognised that they should be teaching the students how to think critically and ethically about the use of technologies.

In the survey the teacher educators were asked how they teach students to integrate different technologies. The responses varied but modelling usage and having students use the technology were the most common methods reported. In the subsequent workshop discussion with teacher educators modelling was identified as very important, however what this meant varied from implicit modelling where teacher educators use digital tools during lecturers and tutorials with the assumption that the students, once introduced to a technology, would explore and integrate this into their practice. At the other end of the spectrum one teacher educator explained how she implemented carefully planned explicit modelling.

While the student teachers do not appear to need teacher education classes to teach them how to use generic tools, technologies that were specifically applied within teaching practice showed a slightly different pattern. While still largely self-taught, the student teachers noted that the courses in their ITE programme played a role in learning to use the technology such as online quizzes, digital games for learning and subject specific digital applications:

I've used a lot of New Zealand maths online resources and that's what I've been pointed in that direction at university. But there is an element of sort of going through things and finding what you need yourself, but I think I've been drawn to it by university and I wouldn't have used it otherwise. (High school student teacher).

\section{Student Data Management Systems}

As part of the professional work of being a teacher, student teachers are expected to learn how to use student data management systems. This includes inputting information and data, analysing and using data and communicating to parents through the system. Learning about student data management systems occurred while on school placement or in ITE courses, with only $6 \%$ of participants reporting that they were self-taught.

What was learnt by the students varied depending on the access they were given to the system and how it was used in the schools in which they were placed. For some students they only used the system to record attendance, while others learnt to use data analysis tools embedded in the systems and drew on the information for both their teaching practice and for assignments in the coursework: 
It was [used] for getting previous results for my diagnostic (testing), to see what curriculum level students were coming in at from their previous unit or from the previous class as I started teaching them through the start of the year, entering in some of their grades. For one of my assignments I did a kind of database search on tracking one of the cohorts Year 9 to Year 13 and extracting information about their, various achievement standards and how that affected what their subject choices in Year 12 and 13. (High school student teacher)

\section{Discussion}

Initial teacher education programmes in New Zealand consist of three key places of learning; the higher education institution, the school placements where student teachers develop their teaching practice and the student teachers' independent study. The participants in this study reported that they predominantly taught themselves how to use digital technologies, with some educational technologies being introduced to them through coursework and some learning through direct teaching or experience in school placements.

Participants were confident in their ability to learn how to use digital technologies once they were aware of relevant tools. This reflects a junction between andragogy, being taught formally as adults and heutagogy, agentic learning beyond the formal programme. This leads to the question of what should be taught and learnt about digital technologies in coursework, in school placements and independently.

\section{Coursework}

The teacher educators and student teachers had differing ideas about what was learnt in the coursework. The teacher educators believed that the students were learning about the use of digital technologies in their courses but few students reported that this was the case. In particular, the teacher educators believed that it was important to be role models in the use of digital technologies.

The expectation that teacher educators should be role models in the use of technology is endorsed in the literature (for example,Uerz, Volman, \& Kral, 2018), however, for role modelling to be effective and help students to translate the observed behaviours into their own practice it must be explicit rather than implicit (Hogg \& Yates, 2013; Lunenberg, Korthagen, \& Swennen, 2007), and ideally through some type of approximation of practice as outlined by Grossman et al (2009). In this study the teacher educators believed they should be role models for the use digital technologies, however this appeared to be through implicit role modelling. This could help explain why the student teachers did not strongly identify learning about digital technologies for teaching from their University courses, apart from being introduced to technologies that they would then learn to use independently.

\section{Learning within school placement}

Student teachers learn about how technology infused within the schooling context is used and managed in practice through school placements. Their experience of observing and teaching using digital technologies and being taught by mentor students and teachers in school gave them the learning opportunities. However, what was evident was that this also created inequitable opportunities with not all students experiencing the same learning opportunities.

Only $60 \%$ of the student teachers had learnt to use student data management systems which are now a key part of the work of a teacher. The way that they are used and what was learnt also varied between students. Those that had learnt to use the student management systems learnt through the school placement or coursework. This lack of knowledge could be attributed to restricted access in schools, the systems are not intuitive and type of use is context specific.

In heutagogical thinking knowledge and skill acquisition is conceptualised as different to deep learning where knowledge and skills can be applied to differing contexts (Hase \& Kenyon, 2007). In this study the student teachers were being asked about their knowledge and skill acquisition, how they learnt to use digital technologies for use in their work as a teacher. For some this did mean relearning what they had previous known for a different purpose and for others it was new knowledge and skill acquisition. The deeper learning required further guidance such as models of critical thinking about the use of technology and pedagogical reasoning processes. This appears to be the role of the teacher education institutions. The practice of applying the skills and knowledge into practice falls into the domain of learning within a school placement. To prepare teachers for 
the digitally infused teaching context there needs to be a non-hierarchical interplay between academic, practitioner, and school based-expertise as suggested by Zeichner (2010).

\section{Conclusion}

The three key sources of learning during initial teacher education the academics who teach in the course-work, student teachers who are agentic in their learning and the school based-experts who mentor all play a complimentary role in preparing students to become teachers in digitally infused contexts. The student teachers learn how to use particular technologies, the academics introduce educational technologies and theoretical or critical frameworks to the students, and the teachers and children in schools mentor the students in the use of technologies in practice.

The key implication emerging from this study are that student teachers do not need to be taught how to use most technologies, they can learn how to use these themselves. What they do need is to know what educational technologies they should use, for what purpose and how to make decisions about technology use. Within their teacher education courses, they should be introduced to subject specific and educational technologies that they can use in their teaching. They should be explicitly taught how to think critically about use within the context of pedagogical decision making and professional practice including the implications of new technologies, ethical practice, evaluating technologies. Within their schooling placements they should learn the use of educational technology in the practice of teaching and be taught how to use student management systems which are context specific. Teachers entering the profession need to learn how to be a teacher in a digitally integrated or infused context rather than being taught how to use technology that they can integrate into their practice.

\section{References}

Blaschke, L. M., \& Hase, S. (2016). Heutagogy: A holistic framework for creating twenty-first-century self-determined learners. In The future of ubiquitous learning (pp. 25-40) Berlin:Springer.

Darling-Hammond, L., \& Bransford, J. (2007). Preparing teachers for a changing world: What teachers should learn and be able to do. NY:John Wiley \& Sons Grossman, P., Compton, C., Igra, D., Ronfeldt, M., Shahan, E., \& Williamson, P. (2009). Teaching practice: A cross-professional perspective. Teachers College Record, 111(9), 2055-2100.

Gudmundsdottir, G. B., \& Hatlevik, O. E. (2017). Newly qualified teachers' professional digital competence: implications for teacher education. European Journal of Teacher Education, 1-17. doi:10.1080/02619768.2017.1416085

Hase, S., \& Kenyon, C. (2000). From andragogy to heutagogy. Ulti-BASE In-Site.

Hase, S., \& Kenyon, C. (2007). Heutagogy: A child of complexity theory. Complicity: An international journal of complexity and education, 4(1).

Hobson, A. J., Malderez, A., Tracey, L., Giannakaki, M., Pell, G., \& Tomlinson, P. D. (2008). Student teachers' experiences of initial teacher preparation in England: core themes and variation. Research Papers in Education, 23(4), 407433. doi:10.1080/02671520701809825

Hogg, L., \& Yates, A. (2013). Walking the talk in initial teacher education: Making teacher educator modeling effective. Studying Teacher Education, 9(3), 311-328.

Instefjord, E. J., \& Munthe, E. (2017). Educating digitally competent teachers: A study of integration of professional digital competence in teacher education. Teaching and Teacher Education, 67, 37-45. doi:https://doi.org/10.1016/j.tate.2017.05.016

Kabakci Yurdakul, I., \& Çoklar, A. N. (2014). Modeling preservice teachers' TPACK competencies based on ICT usage. Journal of Computer Assisted Learning, 30(4), 363-376.

Lunenberg, M., Korthagen, F., \& Swennen, A. (2007). The teacher educator as a role model. Teaching and Teacher Education, 23(5), 586-601.

Merriam, S. B., Caffarella, R. S., \& Baumgartner, L. M. (2006). Learning in adulthood: A comprehensive guide: John Wiley $\&$ Sons.

Røkenes, F. M., \& Krumsvik, R. J. (2014). Development of Student Teachers' Digital Competence in Teacher Education-A Literature Review. Nordic Journal of Digital Literacy, 9(04), 250-280.

Scott, D. and Morrison, M. (2006). Key ideas in educational research, London: Continuum.

Selwyn, N., Nemorin, S., Bulfin, S., \& Johnson, N. F. (2018). Schools in the Digital Age: How might things be otherwise? In Everyday Schooling in the Digital Age: High School, High Tech? (pp. 171-190): Routledge.

Shanti Divaharan, S., Wei-Ying Lim, W., \& Seng-Chee Tan, S. (2011). Walk the talk: Immersing pre-service teachers in the learning of ICT tools for knowledge creation. Australasian Journal of Educational Technology, 27(8), 1304-1318. Retrieved from http://helicon.vuw.ac.nz/login?url=http://search.ebscohost.com/login.aspx? direct $=$ true $\& \mathrm{db}=$ eue $\& \mathrm{AN}=77923949 \&$ site $=$ ehost-live

Starkey, L. (2020). A review of research exploring teacher preparation for the digital age. Cambridge Journal of Education, 50(1), 37-56.

Tang, S. Y., Wong, A. K., \& Cheng, M. M. (2012). Professional learning in initial teacher education: Vision in the constructivist conception of teaching and learning. Journal of Education for Teaching, 38(4), 435-451. 
Tang, S. Y., Wong, A. K., Li, D. D., \& Cheng, M. M. (2019). Re-conceptualising professional competence development of student teachers in initial teacher education. Research Papers in Education, 1-24. doi:10.1080/02671522.2019.1633563

Tondeur, J., Scherer, R., Siddiq, F., \& Baran, E. (2017). A comprehensive investigation of TPACK within pre-service teachers' ICT profiles: Mind the gap! Australasian Journal of Educational Technology, 33(3), 46-60.

Toom, A., Pyhältö, K., \& Rust, F. O. C. (2015). Teachers' professional agency in contradictory times. Teachers and Teaching, 21(6), 615-623.

Uerz, D., Volman, M., \& Kral, M. (2018). Teacher educators' competences in fostering student teachers' proficiency in teaching and learning with technology: An overview of relevant research literature. Teaching and Teacher Education, 70, 12-23.

Zeichner, K. (2010). Rethinking the Connections Between Campus Courses and Field Experiences in College- and University-Based Teacher Education. Journal of Teacher Education, 61(1-2), 89-99. doi:10.1177/0022487109347671

Zeichner, K. (2012). The turn once again toward practice-based teacher education. Journal of Teacher Education, 63(5), 376-382. 